\title{
Benelux
}

\section{Belgium, the Netherlands, and Luxembourg}

\section{Kingdom of Belgium}

Like in the previous year, Belgium started 2020 with a caretaker government. In late 2019, Sophie Wilmès had become the first woman in the office of Belgian Prime Minister, succeeding Charles Michel, who stepped aside to succeed Donald Tusk as the new Chair of the European Council, popularly known as the 'President of Europe'. Wilmès could not form a regular government, as the super election day of 26 May 2019 , when elections were held both on the federal and on the regional levels (contemporaneously with the European election), had once again demonstrated the different political spheres that have emerged in the country and led to a political deadlock in the Belgian federal parliament. Whereas the regional governments, also not without laborious negotiations, could all be formed in late 2019 - the Flemish government under Jan Jambon from the nationalist New Flemish Alliance (N-VA), in a centre-right coalition with the Flemish Christian Democrats (CD\&V) and Flemish Liberal Democrats (Open VId); and the Walloon government under Elio di Rupo from the Socialist Party (SP) in a centre-left coalition with the liberal Reformist Movement (MR) and the Francophone ecologists (Ecolo) -, the stalemate on the federal level necessitated prolonged government formation talks, facilitated by a long list of successive informateurs, appointed by King Philippe to explore options to overcome the political impasse.

Following calls for a national unity government in light of the emerging Coronavirus pandemic (Belgium would be heavily hit, with one of the largest per capita toll of victims in continental Europe), on 17 March 2020, Wilmès was sworn in by the King as regular Prime Minister with full legislative powers, after she had promised to stay in office for six months only and limit herself to dealing with the pandemic and its social and economic consequences. Her new temporary minority government (Wilmès II), consisting of the same ministers as before, was confirmed by a broad parliamentary majority two days later, and Wilmès granted additional special powers on 26 March 2020, allowing her to govern by means of decrees, while the attempts for a federal government with full legislative powers continued unabated. Almost 500 days (494) after the original election, on 1 October 2020, a new coalition government under Prime Minister Alexander de Croo (Open VId) could be finally be formed, succeeding Sophie Wilmès, who carried on as Foreign Minister, again as the first woman in that political office.

De Croo heads a seven party coalition, nicknamed 'Vivaldi-coalition' by the Belgian press, after the composer's violin concerti Four Seasons, representing the four different political families involved: Flemish and Francophone liberals (Open Vld, MR), Flemish and Francophone Social Democrats (sp.a/Forward, PS), Flemish and Francophone Ecologists (Groen and Ecolo) and Flemish Christian Democrats (CD\&V), whereas the Francophone Christian Democrats $(\mathrm{CDH})$ in light of their electoral losses preferred to stay in the opposition, where also the Flemish nationalist parties (N-VA and the far right Vlaams Belang) can be found, next to a number of smaller parties. While commanding a comfortable majority of 87 out of 150 seats, this means that De Croo's government does not have a majority among the Dutch-speaking members of parliament, in spite of Flanders being the largest member state of Belgium, which is a bone of contention to Flemish nationalists. 


\section{Kingdom of the Netherlands}

Like in Belgium, the political debate Netherlands was dominated by the Coronavirus pandemic, with the initially relative relaxed government approach to the virus being tightened in the course of the year, leading to still bad, but less dramatic fatality figures than in Belgium.

Shortly before the first lockdown came into force, in mid-March 2020, King Willem Alexander, caused a stir, when during a state visit to Indonesia, he expressed his regret and offered his apologies for the excessive violence on the part of the Dutch in the immediate post-war years (1945-1949), when the former colonial power had tried to restore its rule over the country. The royal excuse came to the surprise of many observers and has fed into the wider societal debates about the Dutch colonial past and the country's involvement in the slave trade.

The planned large-scale public celebrations of the $75^{\text {th }}$ anniversary of the liberation of the country from Nazi-German occupation in May 2020 largely fell victim to the social distancing regulations, whereas the death of George Floyd in the United States in the same month and the ensuing Black Lives Matter movement sparked large citizen protests also in the Netherlands, with its sizeable immigrant population, in spite of the general lockdown. Large anti-police violence and anti-racism demonstrations, with several thousand participants, took place in Amsterdam and Rotterdam, which in the Dutch context also were directed against specific Dutch traditions like the Black Pete ('zwarte piet'), a highly controversial tradition of having Santa Claus's companion played by black-faced white people in a master-slave narrative.

Throughout the year, large civil disobedience was also organised by the Dutch farmers, protesting with road blockages and public space occupations against government plans to reduce nitrogen emissions by slashing the country's livestock by fifty per cent, as well as what they perceive as an increasingly hostile government regulations and public opinion in general.

A major scandal, which eventually would lead to the resignation of the government of Prime Minister Mark Rutte from the liberal People's Party for Freedom and Democracy (VVD), in mid-January 2021, less than a month before the scheduled breakup of parliament before the next general elections scheduled for March 2021, was the kinderopvangtoeslagenaffaire or childcare benefit fraud scandal, which had been brewing since late 2018 but escalated toward the end of 2020, when a damning parliamentary report laid the responsibility squarely with Rutte's cabinet. As many as 26,000 families had inaccurately been accused by the Dutch tax authorities of fraudulently claiming childcare allowance, and many families been forced into poverty and debt by having to repay the benefits, a process in which the authorities had to admit profiling on the basis of ethnic origins had played a significant role.

On the international level, Britain's leaving the European institutions ('Brexit') posed a major policy challenge, as for the Netherlands this meant losing its closest partner within the European Union. The country looks poised to benefit hugely from financial and other companies relocating to Amsterdam in particular, though, with some reports suggesting that over 400 businesses have already done do. The 2018 announcement by Unilever, originally a merger of two British and Dutch consumer goods companies from the 1920s, to move its headquarter from London to Rotterdam in light of Brexit, on the other hand has been reversed in June 2021 and the Anglo-Dutch multinational's head office remains in the British Capital. 


\section{Grand Duchy of Luxembourg}

Like neighbouring Belgium, Luxembourg was heavily hit by the ongoing public health emergency. On a more positive note, on 29 February 2020 the Grand Duchy became the first country in the world to make all public transport free for all across its entire territory, in an attempt to motivate residents to change their behaviour with regard to the climate crisis and alleviate traffic congestion blamed on the large number of daily commuters from Belgium, France and Germany. 